\title{
The Correction for Spectral Mismatch Effects on the Calibration of a Solar Cell when Using a Solar Simulator
}

Clay H. Seaman

January 15, 1981

Prepared for

U.S. Department of Energy

Through an agreement with

National Aeronautics and Space Administration

by

Jet Propulsion Laboratory

California Institute of Technology

Pasadena, California

(JPL PUBLICATION 81-1) 


\section{DISCLAIMER}

This report was prepared as an account of work sponsored by an agency of the United States Government. Neither the United States Government nor any agency Thereof, nor any of their employees, makes any warranty, express or implied, or assumes any legal liability or responsibility for the accuracy, completeness, or usefulness of any information, apparatus, product, or process disclosed, or represents that its use would not infringe privately owned rights. Reference herein to any specific commercial product, process, or service by trade name, trademark, manufacturer, or otherwise does not necessarily constitute or imply its endorsement, recommendation, or favoring by the United States Government or any agency thereof. The views and opinions of authors expressed herein do not necessarily state or reflect those of the United States Government or any agency thereof. 


\section{DISCLAIMER}

Portions of this document may be illegible in electronic image products. Images are produced from the best available original document. 


\section{The Correction for Spectral Mismatch Effects on the Calibration of a Solar Cell when Using a Solar Simulator}

Clay $H$. Seaman

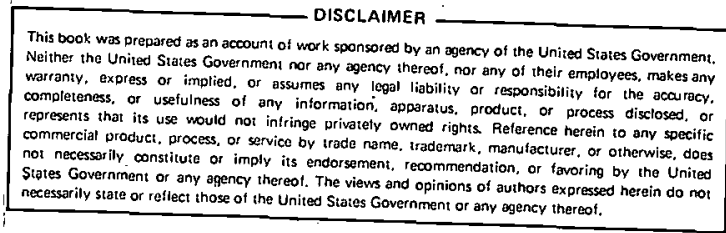

January 15, 1981

Prepared for

U.S. Department of Energy

Through an agreement with

National Aeronautics and Space Administration

by

Jet Prupulsion Laboratory

California Institute of Technology

Pasadena, California

(JPL PUBLICATION 81-1) 
Prepared by the Jet Propulsion Laboratory, California Institute of Technology, for the Department of Energy through an agreement with the National Aeronautics and Space Administration.

The JPL Low-Cost Solar Array Project is sponsored by the Department of Energy (DOE) and forms part of the Photovoltair Fnergy Syetomo Progian lu lullute a major effort toward the development of low-cost solar arrays.

This report was prepared as an account of work sponsored by the United States Government. Neither the United States nor the United States Department of Energy, nor any of their employees, nor any of their contractors, subcontractors, or their employees, makes any warranty, express or implied, or assumes any legal liability or responsibility for the accuracy, completeness or uscfulness of any information, apparatus, product or process disclosed, or represents that its use would not infringe privately owned rights. 


\begin{tabular}{|c|c|}
\hline 2. Government Accession No. & 3. Recipient's Cotalog No. \\
\hline \multirow{2}{*}{$\begin{array}{l}\text { 4. Title and Subtitle } \\
\text { THE CORRECTION FOR SPECTRAL MISMATCH EFFECTS ON THE } \\
\text { CALIBRATION OF A SOLAR CELL WHEN USING A SOLAR } \\
\text { STMULATOR }\end{array}$} & $\begin{array}{l}\text { 5. Report Date } \\
\text { January } 15,1981\end{array}$ \\
\hline & 6. Performing Organization Code \\
\hline 7. Author(s) & 8. Performing Orgonization Report No \\
\hline \multirow{3}{*}{$\begin{array}{l}\text { 9. Performing Organization Nome ond Address } \\
\text { JET PROPULSION LABORATORY } \\
\text { California Institute of Technology } \\
4800 \text { Oak Grove Drive } \\
\text { Pasadena, ' California } 91109\end{array}$} & 10. Work Unit No. \\
\hline & $\begin{array}{c}\text { 11. Contract or Grant No. } \\
\text { NAS } 7-100\end{array}$ \\
\hline & 13. Type of Report and Period Covered \\
\hline \multirow{2}{*}{$\begin{array}{l}\text { 12. Sponsoring Agency Name and Address } \\
\text { NATIONAL AERONAUTICS AND SPACE ADMINISTRATION } \\
\text { Washington, D.C. } 20546\end{array}$} & \\
\hline & icy Code. \\
\hline
\end{tabular}

15. Supplementary Notes

Also sponsored by U.S. Department of Energy under Interagency Agreement DE-A.IOI-76ET20356; “identified as DOE/JPL-1012-50 and JPL Project Document 5101-169. (RTOP 776-52-61).

16. Abstract

A general expression has been derived to enable calculation of the calibration error resulting from simulator-solar AMX spectral mismatch and from.reference cell-test cell spectral mismatch. The information required includes the relative spectral response of the reference cell, the relative spectral response of the cell under test, and the relative spectral irradiance of the simulator (over the spectral range defined by cell response). The spectral irradiance of the solar AMX is assumed to be known.

17. Key Words (Selected by Author(s)) Conversion Techniques Energy Production Energy Storage
18. Distribution Statement

Unclassified - Unlimited 19. Security Clossif. (of this report)
Unclassified
20. Security Clossif. (of this page) Unclassified
21. No. of Pages 9
22. Price 
A general expression has been derived to enable calculation of the calibration error resulting from simulator-solar AMX spectral mismatch and from reference cell-test cell spectral mismatch. The information required includes the relative spectral response of the reference cell, the relative spectral response of the cell under test, and the relative spectral irradiance of the simulator (over the spectral range defined by cell response). The spectral irradiance of the solar AMX is assumed to be known. 
ACKNOWLEDGEMENT

The author wishes to acknowledge valuable discussions with 0 . von Roos and $\mathrm{L}$. Zafonte during the preparation of this paper. 
CONTENTS

I. INTRODUCTION ........................ 1

II. PROCEDURE . . . . . . . . . . . . . . . . . . . . . 1

III. CONCLUSION . . . . . . . . . . . . . . . . . . 3

REFERENCES ............................. 4 


\section{INTRODUCTION}

Expressions for computing the error in short circuit current due to spectral mismatch (when using solar simulators) have been derived in the past (Reference 1), however none has had the generality required to be of universally predictive value. This paper describes the derivation of a general expression for the error and discusses some interesting points developed during that derivation. It also points out that relative spectral measurements will suffice and that absolute spectral measurements are not necessary.

\section{PROCEDURE}

Let a cell $\mathrm{R}$ be a reference cell calibrated (Reference 2) in AMX standard irradiance $J_{A}$ so that its calibration factor $K_{R A}$ is known and hence its short circuit current $I_{R A}$ under that irradiance $J_{A}$ is known. Under a source $S$ of irradiance $J_{S}$ (solar simulator) this cell $R$ will produce a short circuit current $\mathrm{I}_{\mathrm{RS}}$. Similarly, a cell C irradiated by $\mathrm{J}_{\mathrm{A}}$ will produce $\mathrm{I}_{\mathrm{CA}}$ and when irradiated by $\mathrm{J}_{\mathrm{S}}$ will produce $\mathrm{I}_{\mathrm{CS}}$.

The question now arises, can the standard cell $R$ be used to measure (or adjust) the source $S$ so that $I_{C A}$ can be inferred from the measured $I_{R S}$ and $\mathrm{I}_{\mathrm{CS}}$ ? That is, does

$$
\mathrm{I}_{\mathrm{CS}} / \mathrm{I}_{\mathrm{RS}} \stackrel{?}{=} \mathrm{I}_{\mathrm{CA}} / \mathrm{I}_{\mathrm{RA}}
$$

To be general, write Equation 1 as:

$$
\mathrm{I}_{\mathrm{CS}} / \mathrm{I}_{\mathrm{RS}}=m \mathrm{I}_{\mathrm{CA}} / \mathrm{I}_{\mathrm{RA}}
$$

and investigate the properties of $m$. The previously discussed short circuit currents may be written as:

$$
\begin{aligned}
& I_{C S}=\sum E_{S i} R_{C i} \Delta_{i} \\
& I_{R S}=\sum E_{S i} R_{R i} \Delta_{i} \\
& I_{C A}=\sum E_{A i} R_{C i} \Delta_{i} \\
& I_{R A}=\sum E_{A i} R_{R i} \Delta_{i}
\end{aligned}
$$

where

$$
\begin{aligned}
& \mathrm{E}_{\mathrm{Si}}=\text { Source } \mathrm{S} \text { irradiance at spectral position } \mathrm{i} \\
& \mathrm{E}_{\mathrm{Ai}}=\mathrm{AMX} \text { irradiance at spectral position } i \\
& \mathrm{R}_{\mathrm{Ri}}=\text { Response of cell } \mathrm{R} \text { at spectral pusiliui } i
\end{aligned}
$$




$$
\begin{aligned}
\mathrm{R}_{\mathrm{C} i} & =\text { Response of cell } \mathrm{C} \text { at spectral position } i \\
\Delta_{i} & =\text { ith spectral interval width }
\end{aligned}
$$

The sign $\sum$ will be taken to mean summation over al1 $i$.

Now Equation 2 can be written as:

$$
\sum \mathrm{E}_{\mathrm{Si}} \mathrm{R}_{\mathrm{Ci}} \Delta_{\mathrm{i}} / \sum \mathrm{E}_{\mathrm{Si}} \mathrm{R}_{\mathrm{Ri}} \Delta_{\mathrm{i}}=m \sum \mathrm{E}_{\mathrm{Ai}} \mathrm{R}_{\mathrm{Ci}} \Delta_{\mathrm{i}} / \sum \mathrm{E}_{\mathrm{Ai}} \mathrm{R}_{\mathrm{Ri}} \Delta_{\mathbf{i}}
$$

Without loss of generality, let $R_{R i}=\alpha_{i} R_{C i}$ and $E_{A i}=\beta_{i} E_{S i}$. Substituting these in Equation 3 gives

$$
\sum \mathrm{E}_{\mathrm{Si}} \mathrm{R}_{\mathrm{Ci}} \Delta_{\mathrm{i}} / \sum \mathrm{E}_{\mathrm{Si}} \alpha_{i} \mathrm{R}_{\mathrm{Ci}} \Delta_{\mathrm{i}}=m \sum \beta_{\mathrm{i}} \mathrm{E}_{\mathrm{Si}} \mathrm{R}_{\mathrm{Ci}} \Delta_{\mathrm{i}} / \sum \beta_{\mathrm{i}} \mathrm{E}_{\mathrm{Si}} \alpha_{i} \mathrm{R}_{\mathrm{Ci}} \Delta_{\mathrm{i}}
$$

It can be seen that if $\alpha_{i} \equiv \alpha$ a constant (implies $R$ and $C$ match spectrally), or if $\beta_{i} \equiv \beta$ a constant (implies $S$ and $A M X$ match spectrally), then $m \equiv 1$. In this case, i.e., spectral match, $I_{C S} / I_{R S}=I_{C A} / I_{R A}$. If now the source is adjusted so as to make $I_{R S}=I_{R A}$, then $I_{C S}=I_{C A}$, and the short circuit current of cell $\mathrm{C}$ measured with source $\mathrm{S}$ is just that which would be measured in AMX.

In the much more likely event that neither $\alpha_{i}$ nor $\beta_{i}$ is constant (that is, neither sources nor cells match spectrally), $m$, which may be called the mismatch factor, will in general not be equal to unity. However, its value can be computed using Equation 3. Equation 3 may be considered the computation equation for $m$, and Equation 2 may be considered the measurement equation for $\mathrm{I}_{\mathrm{CA}}$.

Notice from the form of Equation 3 that $R_{C i}, R_{R i}$ and $E_{S i}$ need only be relative quantities*. This becomes apparent if we suppose, for example, that the cell spectral response described by $R_{C i}$ is only relative; then there is a constant $\eta$ such that the cell spectral response described by $\eta_{R_{C}}$ is absolute. Substituting $\eta_{R_{C i}}$ for $R_{C i}$ in the numerators of equation 3 we have:

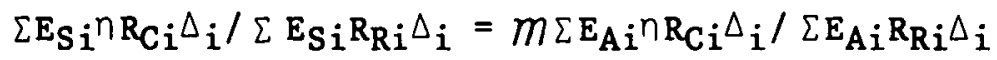

Since $n$ is a constant, it may be taken outside the summation sign, and then dividing both sides by $l$, it is seen that equation 3 remains unchanged. Similar arguments hold for $R_{R i}$ and $E_{S i}$. The importance of this must be emphasized, for now the onus of making absolute measurements of the spectral properties of sources and cells is removed.

*i.e., normalized to arbitrary but convenient references 
In addition to the relaxation of absolutism in the expression for computing $m$, notice that any errors in these measured spectral quantities tend to cancel, since each appears in both numerator and denominator. By contrast, if one were to compute any of the currents in isolation, not only are absolute values required, but all such errors appear fully weighted.

When the source $S$ is set so as to make $I_{R S}=I_{R A}$, and we measure $I_{C S}$, Equation 2 gives:

$$
\mathrm{I}_{\mathrm{CA}}=\mathrm{I}_{\mathrm{CS}} / \mathrm{m}
$$

and since we have independently computed $m$ by Equation 3 , we have determined the value of $\mathrm{I}_{\mathrm{CA}}$ as desired. Alternatively, if the simulator is set so as to make $m_{I_{R S}}=I_{R A}$, we see that $I_{C S}=I_{C A}$ and the short circuit current of cell $C$ measured under source $S$, as now set, is just that which would be measured in AMX.

When the mismatch is ignored, or, in other words, when $m$ is assumed to be unity (as is conventionally done), the fractional error $\varepsilon$ due to equating $I_{C S}$ with $I_{C A}$ will be $\varepsilon=\left(I_{C S}-I_{C A}\right) / I_{C A}$. Using Equation 5 ,

$$
\begin{aligned}
\varepsilon & =\left(m \mathrm{I}_{\mathrm{CA}}-\mathrm{I}_{\mathrm{CA}}\right) / \mathrm{I}_{\mathrm{CA}} \\
& =m-1
\end{aligned}
$$

III. CONCLUSION

The derived expression for the mismatch factor $m$ (Equation 3 ) allows any radiant source of known relative spectral irradiance (known over the spectral range of cell response) to be used to calibrate any cell of known relative spectral response. A standard AMX reference cell of known relative spectral response is required to set the irradialle of the source. Specificallyt

(1) If the simulator is set so as to make $I_{R S}=I_{R A}$, the measured $\mathrm{I}_{\mathrm{CS}}$ will equal $m \mathrm{I}_{\mathrm{CA}}$.

(2) If the simulator is set so as to make $m_{\mathrm{I}_{\mathrm{RS}}}=\mathrm{I}_{\mathrm{RA}}$, the measured $I_{C S}$ will equal $I_{C A}$.

(3) If mismatch is ignored, the fractional error in $\mathrm{I}_{\mathrm{CA}}$ is $\varepsilon=m-1$. 


\section{REFERENCES}

1. Curtis, H. B., "Errors in Short Circuit Current Measurements Due to Spectral Mismatch Between Sunlight and Solar Simulators," Proceedings of Workshop: Terrestrial Photovoltaic Measurements - II, held at Baton Rouge, Louisiana, November 10-12, 1976, NASA CP 2010 p. 161-182.

2. Terrestrial Photovoltaic Measurement Procedures, NASA TM 73702, NASA Lewis Research Center, June 1977. 